Jovana Gardašević ${ }^{1}$

Maja Ćirić ${ }^{2}$

Ivan Stanisavljević ${ }^{3}$

University Business Academy in Novi Sad,
SCIENTIFIC REVIEW ARTICLE

DOI: 10.5937/ekonomika2101077G

Received: October, 28. 2020.

Accepted: December, 14. 2020.

Faculty of Economics and Engineering Management in Novi Sad

\title{
THE RELATIONS BETWEEN CONTEMPORARY LEADERSHIP STYLES AND THE DIMENSIONS OF NATIONAL CULTURE IN MODERN BUSINESS ENVIRONMENT
}

\begin{abstract}
The subject of this paper is the relationship between contemporary leadership styles and the dimensions of national culture. Leaders manifest a particular style of leadership, created under the influence of a large number of elements that determine it. Thus, the national culture is related to the behaviour of leaders in the business system. The aim of the paper is to show how national culture shapes a leadership style. Basic analytical and synthetic methods, methods of induction, deduction and generalization, exploratory method and content analysis were used in the paper. The paper will show that it is important to recognize the influence of the dimensions of national culture on leadership style, as these are concepts that can determine the success of a business. The importance of the work is reflected in the synthesis of literature review on the link between leadership styles and dimensions of national culture and is intended for contemporary leaders who need to improve their business.
\end{abstract}

Key words: national culture, organizational culture, leadership style, leader, contemporary business

JEL classification: M14

\section{РЕЛАЦИЈЕ САВРЕМЕНИХ СТИЛОВА ВОЪСТВА И ДИМЕНЗИЈА НАЦИОНАЛНЕ КУЛТУРЕ У МОДЕРНОМ ПОСЛОВНОМ ОКРУЖЕЊУ}

\begin{abstract}
Апстракт
Предметовоградајестеоднос измеђусавременихстиловавођстваидимензија нациионалне кулутре. Лидери манифестују одређени стил лидерства, креиран под утицајем великог броја елемената који га одређују. Тако је инационална култура доведена у везу са понашањем лидера у пословном систему. Циљ рада је да покаже на који начин национална култура обликује стил лидерства. У раду су коришћене основне аналитичке и синтетичке методе, методе индукције, дедукаиије и генерализаџије, експлораторна метода као и анализа садржаја. Рад ће показати да је важно спознати утицај димензија националне културе
\end{abstract}

\footnotetext{
${ }^{1}$ gardasevic.jovana@gmail.com, ORCID ID 0000-0002-3239-2083

2 majaciric79@yahoo.com, ORCID ID 0000-0002-9557-9881

${ }^{3}$ ivan.stanisavljevic@fimek.edu.rs, ORCID ID 0000-0003-4763-2155
} 
на стил лидерства, јер се ради о појмовима који су блиско повезан и и који могу да определе успех пословања. Значај рада огледа се у синтези ранијих и новијих ставова аутора по питаюу везе између стилова вођства и димензија националне културе и намењен је савременим лидерима који треба да побљшају своје пословане и остваре пословне циљеве.

Кључне речи: национална култура, организациона култура, стил лидерства, лидер, савремено пословање

\section{Introduction}

The aim of this paper is to provide contemporary managers with an overview of literature in the field of organizational culture and leadership styles in a cross-cultural context, in order to improve their business in the context of different cultural milieus and thus ensure adequate business success for themselves and the organization.

The modern business world operates in very changing market conditions. Today's business is characterized by major changes, which occur over a short period of time. Such a situation requires the continued readiness of the organization to respond to the circumstances it faces. The response needs to be systematic, timely and based on knowledge. In today's market, companies need to plan each step ahead and to act according to plans within business opportunities. Organizations carry out their business within a certain organizational culture. In other words, organizational culture is an integral part of organizational behaviour, thus shaping the actions that the organization implements towards its stakeholders. Organizational culture may be more or less formal, but it largely determines each company's relationship to its internal and external environment while working. Organizational culture is influenced by a large number of factors, one of them being national culture. Thus, national culture, through organizational culture, has a significant impact on the leadership style that is implemented within the company.

\section{The importance of national culture in contemporary business}

Today's market is characterized by globalization processes. There is no sphere that has not been touched by globalization. The effects of this phenomenon have largely predetermined the functioning of business systems. Trade liberalization tries to be a part of every market, while the privatization of companies ends within transition economies. The goal is to improve the efficiency and effectiveness of all business systems. Numerous studies have shown that different national cultures play a different role in the functioning of organizational systems. National cultures are also part of the globalization process.

National culture has a strong influence on the organization and management of enterprises arising from its nature and content (Janićijević, 2014a). Even Kluckhohn perceived national culture as patterned ways of thinking, feeling and reacting, acquired and transmitted mainly by symbols, constituting the distinctive achievements of human groups, including their embodiments in artifacts (Kluckhohn, 1951). Hofstede interprets national culture as the collective programming of the mind which distinguishes the members of one group or category of people from another (Hofstede, 2001). Trompenaars defines culture as the way in which a group of people solves problems and reconciles dilemmas set before them (Trompenaars \& Hampden, 1997). 
Each country has its own customs, its own culture and the way it perceives certain situations. This affects the way the business is conducted within its boundaries. As globalization is increasingly manifesting its effects, the need to understand individual national cultures arises. Culture is characterized by: symbols, heroes, rituals, values (Janićijević, 2014b).

Which management practice will be prevalent depends on these elements and their interrelation. National culture also greatly influences the definition of individual values. Individual values are further transferred to organizational cultures. This would mean that there is a very significant link between organizational and national culture and that their interplay plays a major role in achieving business performance. The existence of a strong organizational culture (containing a tightly integrated set of values, beliefs and behaviours) leads to a higher level of productivity and, consequently, to the achievement of the organization's goals (Marcoulides \& Heck, 1993). This is also referred to as the strong culture hypothesis (Dennison, 1984).

In addition to knowing their own organizational culture, each manager needs also to be familiar with the cultures of their clients' countries. It is necessary to master the skills of behaviour in different cultures in order for the business to be successful. By thoroughly analyzing the dimensions of national culture, managers foster and coordinate organizational cultures that are in line with key aspects of national culture (Mojić, 2011). Regardless of the fact that the knowledge, abilities and skills of managers are influenced by that culture, it is necessary to open up to other business practices as well.

The success or failure of a company in the international market depends primarily on its own potential to carry out an objective study of a given market and determine business-defined expertise, but also on the possibilities and ways of its incorporation in a foreign environment (Đokić \& Gardašević, 2013).

The dimensions of national culture represent the basic assumptions shared by members of one national community about key issues each society is facing (Prodović \& Prodović Milojković, 2018).

\section{Contemporary leadership}

Leadership is the process of designing and precisely defining tasks with consistent behaviour of the leader who needs to manifest behaviours in accordance with their speeches (Drucker, 1995). Leadership is a process of interactive and social character, which contains elements embedded in the situation, followers and effects of the work of the leader who determines the meaning and direction of the activity using power (Yukl, 1998). Leadership is the behaviour of an individual who guides activities of a group toward the attainment of a mutual goal (Newstrom, 2008). In the modern age, leadership needs to be seen as a process that allows leaders to act on employees, but in a specific way. They need to find mechanisms whereby they will influence employees, working conditions, the overall process of reaching the set goals, and it is recommended that their manifestation of influence be based on the manifestation of the following behaviours: empowering, enabling, and encouraging (Nešić, 2008). Leadership represents the ability of an individual to step outside their culture, to start evolutionary change processes that are more adaptive (Schein, 2010). In order to achieve a common goal, an influence of an individual on the others in a group is done through the leadership process (Northouse, 2013).

The leader is the creator of the mission and the visionary of the organization. In contrast, the manager's job is to put that vision into practice (Aleksić, 2007). Leaders 
must adhere to the following principles: centralisation, flexibility, availability and importance (Nešić, 2008). There is a classification of circumstances that indicate that a person might grow into a very successful leader one day. The main circumstances related to such an achievement can be identified within the following: challenging tasks in the early years of career, a clear leadership role model, positive or negative, tasks that broaden knowledge in different fields, participation in team projects, the presence of a mentor who is willing to help, taking over responsibilities beyond the primary domain of responsibility, special risky tasks, formal and informal training (Conger, 1992).

An important link on the road to success is leadership, viewed in both dimensions, both of those who are led and those who lead. What requires changes in leadership is a person who has become a knowledge worker, the bearer of most of the assets of an enterprise in the form of intellectual capital, a highly educated individual, a specialist or an expert. As a result of these circumstances, significant changes in leadership are also necessary to successfully exert influence and, consequently, to guide all individuals towards achieving the organization's goals as a measure of business success (Stojanović \& Marić, 2018).

In today's organizations, especially those that are mainly knowledge-based as a key resource in business, there is a continuing need for development (Pearce, Manz, 2005). Traditionally, the greatest efforts in the development of leadership, when it comes to organizations, are generally strictly focused on a formal hierarchical structure. Unlike the traditional approach to leadership development, according to the authors, it is necessary for all employees to be involved and contribute to the development of leadership in order for organizations to prepare their employees for responsible self-leadership and effective implementation of shared leadership (Stojanović \& Marić, 2018).

\section{Characteristics of some leadership styles}

Differentiating between styles of leaders when motivating, mobilizing, and directing their followers has a special place in the study of the phenomenon of leadership.

In this regard, leadership style is in fact nothing more than a form of establishing a relationship between a leader and his followers, but also other employees in one organization, and a form by which the leader directs the behaviour of others in order to go in the desired direction and to achieve the pre-set goals. Over time, three large groups of leadership styles stood out: authoritarian leadership style, democratic leadership style, and free-rein leadership style (Lewin, 2013).

At Ohio University, research was conducted that found that there are two factors that characterize leadership styles. These factors are initiating structure and consideration. A leader with a pronounced initiating structure divides the work and determines who will perform the task and also shapes the relationships within the group. It is he who defines performance standards (Stogdill, 1963).

The program of research at Michigan University identified production orientation and employee orientation. Production-oriented leaders turn their attention to the tasks and want only the task-related goals to be achieved. Employee-oriented leaders want interpersonal relationships to be adequate, to be individual in their considerations, and their personal needs to be met (Bowers \& Seashore, 1966).

Authoritarian leadership style is characterized by centralised decision-making processes in the figure of a leader. It is the leader who directs the activities of the entire group with an individual decision-making style (Blake \& Mouton, 1985). Followers expect clear guidelines from their leaders in societes such as Korea, India or Venezuela. 
Due to the hierarhical differences between the followers and leaders, a strong sense of dependence is expected. The leaders are not questioned by the followers because the followers respect and listen to them (Kirkman, Chen, Farh, Chen \& Lowe, 2009).

Democratic leadership style is characteristic of those groups where the decisionmaking process is group-oriented. The leader makes the final decision only after consultation with all followers or their representatives, and it is especially important that opinions are respected. Democratic leaders are usually such as to draw strength and knowledge from the collective, while motivating them both to collaborate and to deliver concrete results (Blake \& Mouton, 1985). In highly individualistic cultures, like the U.S., the responsibility for own destiny is on an individual. It is believed that in trying to use an authoritative leadership style, the leaders may have difficulty, given that authonomy and uncertanity are highly valued (Dickson, Den Hartog \& Michelson, 2003; Den Hartog, House, Hanges, Ruiz-Quintanilla \& Dorfman, 1999; Janićijević, 2019).

Free-rein leadership style is also called laissez faire. The leader does not guide the group in a formal sense, but allows it to fully express its opinions, to use its knowledge, skills and abilities and to decide which methods, plans and policies should be applied (Fiedler, 1995). Fiedler points out a model that rests on the idea that the effectiveness of a particular leadership style depends on: the specifics of the relationship between the leader and the follower, the clarity of the task structure, the power that the leader possesses. Fiedler argued that there are two types of leader-follower relationship. Relationships between the two persons, or the two sides, can be both good and bad. Leaders are forced to adapt their styles depending on the specifics of the environment, goals, situation and problems they face.

The leadership style and the perceptions of the employee are influenced by the culture (House, Hanges, Javidan, Dorfman \& Gupta, 2004; Jackson, Meyer \& Wang, 2013). Hanges and colleagues empirically confrmed that the cultural background and self-perception influence the employees' perception of leadership. Cultural values of employees in interaction with the leadership behaviour influence the outcomes such as affective, cognitive and behavioural. The leader's behaviour must be in line with the expectations of the followers' culure (Dorfman, Hanges \& Brodbeck, 2004).

With the intensification of the globalization process and the expansion of business across national borders, the concept of culture-specific leadership becomes highly significant. This concept requires leaders to adapt to different cultural environments that create different cultural profiles of people (Jogulu, 2010).

\section{Dimensions of national culture and their impact on leadership}

There is also a big difference between the business culture of the developed countries and the developing countries. The following features are attributed to developing countries: the infrastructure is not sufficiently developed, the workforce is not skilled enough, technological development is not on an appropriate level, political instability is in place, social structures are very rigid, religions have a very significant impact on business, differences between respect for the men's and women's rights are large, which means that these countries are less liberal, individualism is low, there is a high degree of avoiding risks, insecurity and uncertainty, masculine values are low, power distance is low, thinking is associative. It is believed that cultures can be divided according to the following four criteria: power distance, uncertainty avoidance, collectivism, feminine values (Vasilić \& Brković, 2017).

Power distance refers to the extent to which employees have the opportunity to express their views, to participate in the decision-making process, to enjoy the 
circumstances of a democratic approach to management. This dimension can often show the degree of inequality, but viewed from the perspective of those entities that have power. Engelen and colleagues (2014) claims that in the cultures of a high degree of individualism and a low power distance, the effectiveness of high performace innovation expectations are higher. The involement of followers and their contribution to decision making is characteristic of societies with a small distance of power in which hierarchical differences do not stand out (Javidan, Dorfman, De Luque, \& House, 2006). In societies with a high distance power, in which hierarhical differences stand out, intellectual stimulation of followers by a transformational leader is not advisable because he could be accused of incompetence (Hofstede 2001; Javidan et al. 2006).

Uncertainty avoidance mainly refers to decision-making processes. There are cultures within which it is desirable to make decisions in environments that are uncertain and where a high level of risk is considered to be associated with profit and good business results. Cultures with high uncertainty avoidance have a considerable aversion to something they encounter for the first time, whereas in nations with low uncertainty avoidance, the unknown is viewed as a chance to be even better (Janićijević \& Marinković, 2015). A high level of uncertainty avoidance in a culture leads to authoritarian leadership, while a low level of uncertainty avoidance leads to participative leadership (Yukl, 2013).

The individualism/collectivism dimension addresses the issue of the relationship between the individual and the collective (Hofstede \& Bond, 1984). Collectivism refers to the degree to which personal interests are subordinated to collective interests. Collective cultures are those cultures in which personal interests are put aside, all of which are subordinated to the common good. Individualism, on the one hand, in contrast to its opposite - collectivism, is primarily a social rather than an individual characteristic that expresses the degree to which people in society are integrated into groups (Gardašević, 2019). Collectivist national cultures nurture the values of empathy, harmony, respect, self-control, security, so that leaders in these cultures pay more attention to meeting the needs of others than achieving their own goals, and employees embrace performance standards by caring for the well-being of the collective as a whole. In collectivist cultures people are more prone to identify themselves with the group and the common vision or goals of the group are usually shaped by a charismatic leader. In individualistic cultures it is harder for a charismatic leader to emerge since all people are predominantly driven by their own interests and rational calculations (Janićijević, 2019). In collectivist cultures where maintaning harmony exceeds performace expectations, high performance expectations are not effective (Spreitzer, Perttula \& Xin, 2005).

Feminine values and masculine values largely determine the way of doing business in certain national cultures. The degree of masculinity of a culture refers to the need for proving oneself, aggressiveness, materialism, competitive spirit. The feminine qualities are conciliatoriness and caringness. In masculine cultures, both women and men are more eager to prove themselves. In masculine cultures, leaders are ambitious and dominant, and they are expected to be responsible for success, while in feminine cultures, leaders tend to negotiate (Milovanović, 2014). Leaders in masculine cultures more often apply task oriented style, while leaders in feminine cultures apply people oriented style. In masculine cultures, the leader is usually aggressive and assertive and has typical male qualities. In feminine cultures, the leader is less visible, more prone to consensus, and has both male and female qualities (Janićijević, 2019).

The level of uncertainty avoidance also affects leadership styles, so that in cultures where this level is high, leaders formulate clear rules and pay special attention to planning, whereas in cultures with a low level of risk avoidance, leaders and employees 
do not feel uncomfortable with volatile situations and are more open to changes and experiments. The leader in such cultures, usually the collectivist ones, has the task to protect his/her followers from uncertainty, and in return, the followers give the leader their complete loyalty and put all the power in his/her hands. The consequence is, of course, authoritarian people-oriented leadership. The leader is expected to be omnipotent and the leader's confidence is highly appreciated (Hofstede, 2001). In all cultures, employee innovation is facilitated by transformational leadership. One study conducted in 17 countries found that, regardless of national boundaries, transformational leadership is correlated with innovation, both at the individual, and at the group level. In countries with higher levels of uncertainty avoidance, this correlation is stronger. This research suggests that investing in transformational leadership can improve employee innovation, in most countries, but especially in the countries with a higher level of uncertainty avoidance (Watts, Steele \& Den Hartog, 2020).

In one of the last studies, the authors analyzed the meetings of a working team in a corporation using a microanalytical technique. According to this research, leadership is practiced in different ways even when the team leaders are of the same national culture (Swedish). Namely, all participants jointly build the leadership. This paper emphasize the importance of understanding the authentic discourse of leadership and gives the guidelines for overcoming cultural differences and stereotypes, important for the future researches (Chan \& Du-Babcock, 2019).

\section{Relations between organizational culture, leadership and national culture}

In recent years, the opinion that there is a very pronounced impact of organizational culture on the performance of the company has become prevalent in the organizational and management theory and practice (Sapić, Erić \& Stojanović Aleksić, 2009).

Organizational culture is made up of several factors and influences. If we look at the actors who are directly involved in the life of culture in an organization that directly or indirectly creates it, there are individual values, the dynamics of development and influence, the leader and his role. Changes in organizational culture should be initiated by the top management (Medenica-Mitrović \& Popović, 2019).

Research examining the variation of the influence of internal (organizational hierarchy) factors and external (national) factors for the first time reveals the importance of these factors in the way organizational culture is viewed. Their results address the impact of power through different levels of organizational culture. Thus, how the perception of security culture is interpreted in different organizational roles depends on the interaction of national distance of power and power arising from positions within the organization (Tear, Reader, Shorrock \& Kirwan, 2020).

Many authors use the term "iceberg" (Figure 1) to refer to the content of organizational culture. The tip of the iceberg includes the elements that are easily visible in one organization (symbolic elements), while the "deep water" includes informal elements (Milanović, Cvijanović \& Lazić, 2010). 
Figure 1: Iceberg - Visible and invisible level of organizational culture

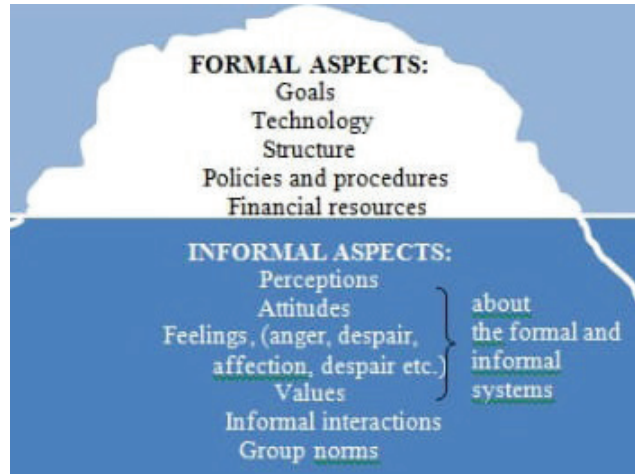

Source: Milanović, T., Cvijanović, J. \& Lazić, J. (2010): Organizational Culture and Change

One of the basic classifications of organizational cultures can be defined by taking the degree of risk associated with the business and the speed of feedback on how successful the business ventures are as a criterion. Accordingly, the following organizational cultures are defined: the tough-guy macho culture, the "work hard play hard" culture, the bet your company culture and the process culture (Cvijanović, 2006).

The tough-guy macho culture is considered to be a typical culture for all organizations that have a high degree of risk in their business, therefore it is very important that all functioning be focused on the recognition of opportunities and the processes of rapid decision making in changing environments. It is particularly important to emphasize that the basic feature of this culture is distrust and orientation, which is not long-term. Within this culture there is a lack of collegiality and individualism comes first. Success is also known to come in a very short time, but it is not a long line between success and failure in the company (Pržulj, 2000).

The work hard play hard culture refers to an action-based culture that includes many forms of entertainment. This culture is characterized by mobility, fluctuation, and emphasis on quantity rather than quality. Reflections are not long-term oriented, hence success is not too much worried about (Drašković, 2014).

The bet your company culture refers to all companies whose business is conducted under conditions of insecurity and uncertainty. Organizations operating under such circumstances are mainly forward-looking and show a high degree of interest in investments. They are constantly reviewing their decisions and looking at them from a cost-effectiveness perspective. Members of this culture are independent in their work, but also seek feedback for their engagement (Handy, 1993).

The process culture, that is, the administrative culture, refers to a business in which the risk is not particularly pronounced. They are characterized by hierarchical relations, and cooperation occurs mainly on a vertical basis. These companies are not particularly interested in feedback and are largely closed to external stakeholders. They follow procedures and rules and it is not advisable to work outside of them. Reviewing efficiency and effectiveness is not frequent (Janićijević, 2013).

It has been proven that there is a very close link between organizational structure and organizational culture. In this regard, four cultures that can occur within organizations have been identified. They are: the power culture, the role culture, the task culture and the support culture (Cvijanović, 2006). 
Centralization of leader power is typical of transactional leader, who is not inclined to delegate important tasks and responsibilities to his subordinates. Should a leader in such cultures attempt to involve employees in the decision-making process by delegating authority to them, employees would perceive such a leader as incompetent because they believe that the manager is paid to think. On the contrary, in cultures with low power distance, the expected leadership style is transformational. People in such cultures have a negative attitude towards the idea of a high concentration of power in one person, as it is perceived as dictatorial and undemocratic, and they find it more rational and efficient to have decision-making power delegated to more people (Vasilić \& Brković, 2017).

Sarros, Gray and Densten (2002) conducted a study that found that leadership explained a higher percentage of variability in organizational culture $(24 \%)$ than organizational culture explained variability in leadership styles $(13 \%)$. From this we can see that the leader has more influence in determining the type of organizational culture than the organizational culture in determining the leadership style, but that there is mutual influence.

National cultures differ most in values, while organizational cultures differ most in: symbols, values, rituals (Janićijević, 2014b).

Research by another group of authors who argue that organizational culture influences leadership is not negligible. They show us that already established organizational cultures with established assumptions, values and beliefs impose certain rules of behaviour to the leader and that if he or she does not follow these rules, the leader cannot remain who he is (Nikolov, 2019).

A high degree of centralization of decision-making and formalization of roles and a preference for an organizational model of full bureaucracy is found in national cultures that have a high distance of power and high avoidance of uncertainty, as is the case with Serbia and other countries of the former Yugoslavia, and Latin American countries. The tendency to apply a high degree of formalization but a low degree of centralization to structuring as well as a model of professional bureaucracy is found in cultures with a low power distance but a high avoidance of uncertainty, which include the national culture of Germany (Ilić, Andrejić, Janošević \& Ilić, 2019).

\section{Conclusion}

Modern business brings with it new rules that create new circumstances within which the activities of the organizational system will be realized. It is recommended that company management recognize its existing organizational culture, in order to identify room for improvement and to implement new principles of operation and management.

Defining the right set of factors that make up a leader is a very complicated task and a generally accepted solution is difficult to reach. The reason for this lies in the fact that each time carries some of its specifics that distinguish a particular type of leader that fits that time. Leadership style depends on many factors and it is clear that it is important to consider a number of factors when deciding on an efficient and effective leadership style.

Leadership style determines the organization's business to a great extent, since the right choice of leadership directly influences the process, which is crucial in the field of employee management. National culture defines people's behaviour, and people's behaviour reflects on the business organization in which they perform their tasks. This gives the impression that national culture largely determines the behaviour of all employees, including leaders. The specificity of 
the national culture and leadership style applied in a company are closely related. Therefore, the recommendations for modern management are related to the necessity of looking for a link between the two concepts, in order to fully explain the behaviour of the leader in a company and to make sure that it is put into the function of achieving business results.

The importance of this paper is reflected in the synthesis of literature that connects contemporary leadership styles with the dimensions of national culture, as well as contemporary leadership styles with organizational culture, and indicates the importance of respecting them.

The paper is aimed at contemporary management and young leaders who can draw the most important conclusions from the overview of the leading views presented in this paper. Leaders are advised to know and respect the different cultural contexts and to be familiar with the organizational culture of the organization in which they operate, in order to better realize their leadership and management skills and thus contribute to the achievement of the ultimate goals of the organization.

The shortcomings of this paper are reflected in the absence of empirical research, therefore its implementation can be viewed as a suggestion for further research.

\section{References}

Aleksić, A. (2007). Uloga i značaj liderstva u uslovima globalnog poslovanja. Sociologija, 49(2), 145-160.

Blake, R. \& Mouton, S. (1985). The managerial grid III. Houston: Gulf Publishing Company.

Bowers, G. \& Seashore, E. (1966). Predicting organizational effectiveness with a four-factor theory of leadership. New York: Administrative Science Quarterly.

Chan, A. C. \& Du-Babcock, B. (2019). Leadership in action: an analysis of leadership behaviour in intercultural business meetings. Language and Intercultural Communication, 19(2), 201-216.

Conger, J. (1992). Learning to lead: The art of transforming managers into leaders. San Francisco, CA: Jossey-Bass.

Cvijanović, J. (2006). Korporativna kultura i organizaciona struktura. Beograd: Ekonomski institut.

Den Hartog, D.N., House, R.J, Hanges, P.J., Ruiz-Quintanilla, S.A. \& Dorfman, P.W. (1999). Culture specific and cross-culturally generalizable leadership theories: Are the attributes of charismatic/transformational leadership universally endorsed? Leadership Quarterly, 10, 219-256.

Dennison, D. (1984). Bringing Corporate Culture to the Bottom Line. Organizational Dynamics, 13 (2), 5-22.

Dickson, M.W., Den Hartog, D. N. \& Michelson, J.K. (2003). Research on leadership in crosscultural context: Making progress and raising new questions. Leadership Quarterly, 14, 729-768.

Dorfman, P. W., Hanges, P. J. \& Brodbeck, F. C. (2004). Leadership and culture variation: The identification of culturally endorsed leadership profiles. In R. J. House, P. J. Hanges, M. Javidan, P. W. Dorfman, \& V. Gupta (Eds.), Culture, leadership, and organizations: The GLOBE study of 62 societies. Thousand Oaks, CA: Sage Publications. 
Drašković, B. (2014). Lider-kreator organizacionih promena. Beograd: Fakultet za ekonomiju, finansije i administraciju.

Drucker, P. (1995). Managing in a Time of Great Change. New York: Truman Talley Books/Plume.

Đokić, M. \& Gardašević, J. (2013). Značaj kulture u međunarodnom marketingu. Časopis za ekonomiju i tržišne komunikacije, 4 (1), 44-55.

Engelen, A., Schmidt, S., Strenger, L. \& Brettel, M. (2014). Top management's transformational leader behaviours and innovation orientation: A cross-cultural perspective in eight countries. Journal of International Management, 20(2), 124-136.

Fiedler, E. (1995). Reflections by an accidental theorist. New York: Leadership Quarterly.

Gardašević, J. (2019). Kulturološke razlike u motivima korišćenja društvenih mreža. Doktorksa disertacija. Fakultet za ekonomiju i inženjerski menadžment u Novom Sadu, Univerzitet Privredna akademija u Novom Sadu, Novi Sad, Srbija.

Handy, C. (1993). Understanding Organizations. (4 ${ }^{\text {th }}$ Ed.) London: Penguin Books.

Hanges, P., Lord, R. \& Dickson, M. (2000). An information-processing perspective on leadership and culture: A case for connectionist architecture. Applied Psychology, 49(1), 133-161.

Hofstede, G. \& Bond, M. H. (1984). Hofstede's culture dimensions: An independent validation using Rokeach's value survey. Journal of cross-cultural psychology, 15(4), 417-433.

Hofstede, G. H. (2001). Culture's consequences: Comparing values, behaviors, institutions and organizations across nations. Thousand Oaks, CA: Sage Publications.

House, R. J., Hanges, P. J., Javidan, M., Dorfman, P. W. \& Gupta, V. (2004). Culture, leadership and organizations: The GLOBE study of 62 societies. Thousand Oaks, CA: Sage Publications.

Ilić, Đ., Andrejić, M., Janošević, M. \& Ilić, S. (2019). Uticaj nacionalne kulture na proces upravljanja organizacionim promenama. Vojno delo, 71(7), 419-440.

Jackson, T. A., Meyer, J. P. \& Wang, X.-H. (2013). Leadership, commitment, and culture: A meta analysis. Journal of Leadership \& Organizational Studies, 20(1), 84-106.

Janićijević, N. (2013). Organizaciona kultura. Beograd: Ekonomski fakultet.

Janićijevć, N. (2014a). Uloga nacionalne kulture u izboru strategije promena u organizacijama. Ekonomski horizonti, 16(1), 3-15.

Janićijević, N. (2014b). Uticaj organizacione kulture na organizaciono učenje, upravljanje znanjem i konkurentnost. Beograd: Ekonomski fakultet.

Janićijević, N. \& Marinković, I. (2015). Empirical testing of Hofstede's measures of national culture and their impact on leadership in four countries. Ekonomika preduzé́a, 63(5-6), 264-278.

Janićijević, N. (2019). The impact of National Culture on Leadership. Economic Themes, 57 (2), 127-144.

Javidan, M., Dorfman, P. W., De Luque, M. S. \& House, R. J. (2006). In the eye of the beholder: Cross cultural lessons in leadership from project GLOBE. The Academy of Management Perspectives, 20(1), 67-90. 
Jogulu, D. (2010). Culturally-Linked Leadership Styles. Leadership \& Organization Development Journal, 31(8), 705-719.

Kirkman, B. L., Chen, G., Farh, J.-L., Chen, Z. X. \& Lowe, K. B. (2009). Individual power distance orientation and follower reactions to transformational leaders: A cross-level, cross-cultural examination. Academy of Management Journal, 52(4), 744-764.

Kluckhohn, (1951). The Study of Culture. In The Policy Sciences. Stanford: Stanford University Press.

Lewin, K. (2013). Frontiers in Group Dynamics. California: SAGE.

Marcoulides, G.A. \& Heck, R.H. (1993).Organizational Culture and Performance: Proposing and Testing a Model. Organization Science, 4 (2), 209-225.

Medenica-Mitrović, D. \& Popović, M. (2019). Correlation and importance of socially responsible business and organizational culture of companies. South Eastern European Journal of Communication, 1(1), 81-89.

Milanović, T., Cvijanović, J. \& Lazić, J. (2010). Organizaciona kultura i promene. Beograd: Železnička tehnička škola.

Milovanović, V. (2014). Uticaj nacionalne kulture na efekte sprovođenja menadžmenta ukupnog kvaliteta. Megatrend revija, 11 (2), 190-192.

Mojić, D. (2011). Uticaj nacionalnih kulturnih vrednosti na organizacionu kulturu i poslovnu praksu. Singidunum revija, 8(2), 145-151.

Nešić, L. (2008). Znati biti lider. Novi Sad: AB Print.

Newstrom, J. (2008). Leader and Leadership Proces. New York: McGraw- Hill.

Nikolov, I. (2019). Uticaj lidera na kreiranje i održavanje organizacione kulture. (Diplomski rad). Univerzitet u Beogradu, Fakultet bezbednosti, Retrieved March10,2020 from:

https://fedorabg.bg.ac.rs/fedora/get/o:20018/bdef:Content/get

Northouse, P. (2013). Leadership, Theory and Practice. Thousand Oaks, CA: Sage Publications.

Pearce, C. L., \& Manz, C. C. (2005). The new silver bullets of leadership: The importance of self-and shared leadership in knowledge work. Organizational Dynamics, 34 (2), 130-140.

Prodović, B. \& Prodović Milojković, B. (2018). Hofstedov model nacionalnih dimenzija sa posebnim osvrtom na vrednosne dimenzije srpske nacionalne kulture. Srpska politička misao, 59 (1), 225-244.

Pržulj, Ž. (2000). Kultura i preduzetništvo. Beograd: Zadužbina Andrejević.

Sarros, J. C., Gray, J. \& Densten, I. L. (2002). Leadership and its impact on organizational culture. International Journal of Business Studies, 10(2), 1-26.

Schein, E. (2010). Organizational Culture and Leadership. San Francisco: JosseyBass Publishing.

Spreitzer, G. M., Perttula, K. H. \& Xin, K. (2005). Traditionality matters: An examination of the effectiveness of transformational leadership in the United States and Taiwan. Journal of Organizational Behavior, 26(3), 205-227.

Stogdill, M. (1963). Manual for the Leader Behavior Description, Questionnaire form XII. Columbus: Ohio State University of Business Research. 
Stojanović, S. \& Marić, S. (2018). Komunikacija kao mera performanse liderstva. Anali Ekonomskog fakulteta u Subotici, (40), 81-94.

Šapić, S., Erić, J. \& Aleksić, V. S. (2009). Uticaj organizacione i nacionalne kulture na prihvatanje organizacionih promena: istraživanje u srpskim preduzećima. Sociologija/Sociology: Journal of Sociology, Social Psychology \& Social Anthropology, 51(4), 399-422.

Tear, M. J., Reader, T. W., Shorrock, S. \& Kirwan, B. (2020). Safety culture and power: Interactions between perceptions of safety culture, organisational hierarchy, and national culture. Safety science, 121, 550-561.

Trompenaars, F. \& Hampden, T. (1997). Riding the Waves of Culture. London: Nicholas Brealey Publishing.

Vasilić, N. \& Brković, P. (2017). Nacionalna kultura kao determinanta stavova o stilovima liderstva. Škola biznisa, 2, 38-55.

Watts, L. L., Steele, L. M. \& Den Hartog, D. N. (2020). Uncertainty avoidance moderates the relationship between transformational leadership and innovation: A meta-analysis. Journal of International Business Studies, 51(1), 138-145.

Yukl, G. (1998). Leadership in Organizations, 9/e. Pearson Education India.

Yukl, G. (2013). Leadership in organizations. ( $8^{\text {th }}$ Ed.) Harlow, VB: Pearson. 